\title{
Gadolinium leakage in ocular structures after stroke in giant-cell arteritis
}

\author{
Dimitri Renard $\odot$, ${ }^{1}$ Khadidja Medini, ${ }^{1}$ Nicolas Gaillard ${ }^{2}$ Eric Thouvenot ${ }^{1}$
}

${ }^{1} \mathrm{CHU}$ de Nîmes, Univ. Montpellier, Nimes, France ${ }^{2} \mathrm{CHU}$ de Montpellier, Univ. Montpellier, Montpellier, France

\section{Correspondence to} Professor Eric Thouvenot; eric.thouvenot@chu-nimes.fr

Accepted 12 July 2020

\section{Check for updates}

(C) BMJ Publishing Group Limited 2021. No commercial re-use. See rights and permissions. Published by BMJ.

To cite: Renard D, Medini K,
Gaillard N, et al. BMJ Case
Rep 2021;14:e235760.
doi:10.1136/bcr-2020-
235760

\section{DESCRIPTION}

An 82-year-old woman with a history of treated hypertension and hypercholesterolemia presented with headache, jaw claudication and elevated C-reactive protein $(106 \mathrm{mg} / \mathrm{L})$. Based on temporal artery biopsy results, a diagnosis of giant cell arteritis was made and oral steroid (prednisone $60 \mathrm{mg}$ once daily (od)) treatment was started. Two weeks later, the patient presented with right-sided anterior ischaemic optic neuropathy and persistence of initial symptoms. Ophthalmological evaluation showed the absence of central retinal artery occlusion. Add-on treatment with intravenous tocilizumab $(8 \mathrm{mg} / \mathrm{kg})$ was started. One month and a half later (after recovery of ophthalmological symptoms), she presented with transient left hemiplegia. MRI showed a small right middle/anterior cerebral artery (MCA/ACA) borderzone infarction, extensive right MCA and limited left MCA/ACA borderzone hypoperfusion, and severe (probably giant cell arteritis-related) bilateral intracranial (ophthalmic C6 segment) carotid stenosis on gadoliniuminjected MRA (figure 1). CTA confirmed severe bilateral carotid stenosis in the absence of atheromatous plaques. Two days later, MRI (performed to assess the evolution of diffusion-weighted imaging and perfusion-weighted imaging abnormalities) showed right-sided gadolinium leakage (originating from gadolinium administered during the initial MRI) in ocular structure (GLOS) restricted to the vitreous body. Despite 3 days of intravenous methylprednisolone $1000 \mathrm{mg} /$ day, the patient represented with transient left hemiplegia. The patient was treated with carotid stenting without procedural complications or neurological symptom recurrence. Angiography (performed for stenting)

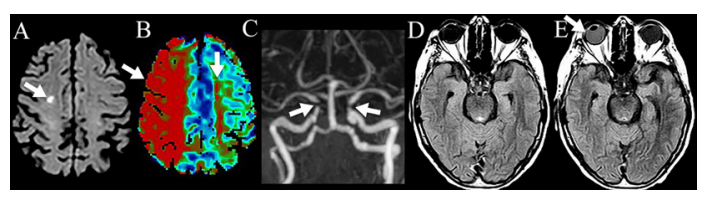

Figure 1 Initial MRI showing a small right MCA/ ACA borderzone infarction (A, diffusion-weighted imaging), extensive right MCA and limited left MCA/ ACA borderzone hypoperfusion (B, perfusion-weighted imaging, time-to-peak MAP), severe bilateral intracranial carotid stenosis on gadolinium-injected MRA (C), and normal hypointense signal of both vitreous bodies ( $D$, FLAIR). MRI 2 days later showing right-sided gadolinium leakage in ocular structure (E, FLAIR). MCA/ACA, middle/ anterior cerebral artery; FLAIR, fluid-attenuated inversion recovery.

\section{Learning points}

- Intracranial stenting (considered as a treatment choice at risk, especially in suspected arterial wall inflammation) may be considered in patients with ongoing aggressive medical treatment, pre-occlusive arterial stenosis and persisting fluctuating neurological deficit.

- Gadolinium leakage in ocular structure (GLOS) probably represents a remote effect of acute cerebral injury on blood-ocular barrier.

- GLOS can be observed in patients with different stroke subtypes and is associated with increasing age and white matter hyperintensities on MRI.

showed carotid stenosis just proximal of the origin of the ophthalmic artery.

Although potentially considered as a treatment choice at risk (especially in a patient with suspected arterial wall inflammation), stenting may be considered in patients with ongoing aggressive medical treatment, pre-occlusive arterial stenosis and persisting fluctuating neurological deficit. ${ }^{1}$

GLOS is a common finding in different stroke subtypes (eg, carotid artery stenosis/occlusion, lacunar infarction), probably representing a remote effect of acute cerebral injury on blood-ocular barrier. ${ }^{2}$ GLOS presence in acute stroke is associated with increasing age and white matter hyperintensities, possibly reflecting insufficient collateralisation. ${ }^{2}$ GLOS can be bilateral symmetrical, bilateral asymmetrical or unilateral. In case of asymmetrical GLOS, GLOS is observed ipsilateral to the brain involvement (thought to be related to impaired asymmetrical collateralisation). ${ }^{1-3}$ To the best of our knowledge, this is the first case of giant cell arteritis-related infarction associated with GLOS. In our case, possible underlying aetiologies explaining GLOS include giant cell arteritis-related ischaemic optic neuropathy, ophthalmic artery (originating distal of the severe carotid artery stenosis) involvement or simply a remote effect of the brain infarction (like seen in classic stroke cases).

Contributors DR, KM and ET contributed to the acquisition and analyses of the data, the concept of the manuscript, the writing and editing of the paper. NG contributed to the acquisition and analyses of the data, and the concept of the manuscript.

Funding The authors have not declared a specific grant for this research from any funding agency in the public, commercial or not-for-profit sectors,

Competing interests None declared.

Patient consent for publication Obtained. 
Images in...

Provenance and peer review Not commissioned; externally peer reviewed.

\section{REFERENCES}

ORCID iD

Dimitri Renard http://orcid.org/0000-0002-3511-8151

1 Guerrero AM, Sierra-Hidalgo F, Calleja P, et al. Intracranial internal carotid artery angioplasthy and stenting in giant cell arteritis. J Neuroimaging 2015;25:307-9.

2 Hitomi E, Simpkins AN, Luby M, et al. Blood-ocular barrier disruption in patients with acute stroke. Neurology 2018;90:e915-23.

3 Förster A, Wenz H, Böhme J, et al. Asymmetrical gadolinium leakage in ocular structures in stroke due to internal carotid artery stenosis or occlusion. Clin Neuroradiol 2020;30:221-8.

Copyright 2021 BMJ Publishing Group. All rights reserved. For permission to reuse any of this content visit

https://www.bmj.com/company/products-services/rights-and-licensing/permissions/

BMJ Case Report Fellows may re-use this article for personal use and teaching without any further permission.

Become a Fellow of BMJ Case Reports today and you can:

- Submit as many cases as you like

- Enjoy fast sympathetic peer review and rapid publication of accepted articles

Access all the published articles

Re-use any of the published material for personal use and teaching without further permission

\section{Customer Service}

If you have any further queries about your subscription, please contact our customer services team on +44 (0) 2071111105 or via email at support@bmj.com.

Visit casereports.bmj.com for more articles like this and to become a Fellow 